\title{
Analisis Retrofit Lampu Di Kantor Wilayah BRI Denpasar Dengan Metode Life Cycle Cost
}

\author{
Muhammad Hari Wijaya ${ }^{1}$, Rukmi Sari Hartati ${ }^{2}$, Wayan Gede Ariastina ${ }^{3}$ \\ [Submission: 22-08-2019, Accepted: 22-08-2019]
}

\begin{abstract}
Lighting is one of the primary of human needs everywhere, because the presence of lighting will help human activity and productivity. By the development of technology and innovation in energy saving lamps (LEDs), it's possible to save power and electricity use. Excessive use of lights can certainly be a separate problem as happened in BRI Regional Office Denpasar. These problems are interesting issues to be learned and solved. Considering the electricity used by BRI Denpasar Regional Office building sourced from the National Electric Company, it certainly will help to find ways for getting the required lighting with the minimum expenditure costs. In this study, the calculation of LED lighting savings uses the Life Cycle Cost (LCC) method and also the calculation of economic feasibility.
\end{abstract}

As a result, the initial cost of replacing the Philips brand LED lights requires a cost of $R$ p.145,093,000.00 while the initial cost for existing lights is Rp.48,856,000.00. The energy saving that will be obtained is $11,309.49 \mathrm{kWh}$ per month, so that the bill savings obtained with the electricity tariff per $\mathrm{kWH}$ of $\mathrm{Rp.1,117.00}$ is $\mathbf{R p}$. $12,632,700.00$ every month. The operational cost of LED lights was originally Rp.132,172,421.00 will experience a gradation of inflation rate of $4.2 \%$ so that during the life time of the lamp (4 years) it will be a total of Rp.562,939,535.08. The total LED LCC is Rp. 708,032,535.08 greater than the total LCC of the existing lamp, which is Rp. 628,293,771.91.

The economic feasibility studies using the PBP method, NPV, IRR and PI show results that are feasible to receive because they provide benefits to users in the form of energy saving and bill saving.

Intisari- Penerangan merupakan salah satu kebutuhan primer manusia dimanapun berada, karena dengan adanya penerangan akan sangat membantu aktivitas dan produktivitas manusia. Dengan adanya perkembangan teknologi dan inovasi pada lampu hemat energi (LED) telah dimungkinkan terjadinya penghematan daya dan biaya penggunaan listrik. Penggunaan lampu yang banyak tentu bisa menjadi masalah tersendiri seperti yang terjadi pada Kantor Wilayah BRI Denpasar. Permasalahan tersebut menarik untuk diteliti dan diselesaikan. Mengingat listrik yang digunakan oleh gedung Kantor Wilayah BRI Denpasar bersumber dari PLN, tentu ini akan membantu menemukan cara untuk bisa mendapatkan penerangan yang dibutuhkan dengan biaya pengeluaran seminimal mungkin. Pada penelitian ini dilakukan perhitungan penghematan lampu LED menggunakan metode Life Cycle Cost (LCC) dan juga perhitungan kelayakan ekonomi.

${ }^{1}$ Pekerja BRI dan Mahasiswa Pascasarjana, Teknik Elektro Fakultas Teknik Universitas Udayana, Jln. Jalan Kampus Bukit Jimbaran 80361 INDONESIA (tlp: 0361-703315; fax: 0361-703315; e-mail:m_hari_wijaya@yahoo.com)

${ }^{2,3}$ Dosen, Jurusan Teknik Elektro dan Komputer Fakultas Teknik Universitas Udayana, Jln. Jalan Kampus Bukit Jimbaran 80361 INDONESIA (telp: 0361-703315; fax: 0361-703315; e-mail: rukmisari@unud.ac.id,w.ariastina@unud.ac.id)
Hasilnya, initial cost (biaya investasi) penggantian menjadi lampu LED merek Philips membutuhkan biaya Rp.145.093.000,00 sedangkan initial cost untuk lampu existing adalah sebesar Rp.48.846.000,00. Energy saving yang akan diperoleh adalah 11.309,49 $\mathrm{kWh}$ setiap bulannya, sehingga bill saving yang diperoleh dengan tarif listrik per kWH Rp.1.117,00 adalah Rp. 12.632.700,00 setiap bulannya. Operational Cost (biaya operasional) lampu LED yang semula Rp.132.172.421,00 akan mengalami gradasi sebesar angka inflasi sebesar 4,2\% sehingga selama life time lampu (4 tahun) akan menjadi total Rp.562.939.535,08. Total LCC lampu LED yaitu Rp. 708.032.535,08 lebih besar bila dibandingkan dengan total LCC lampu existing yaitu Rp.628.293.771,91.

Studi kelayakan ekonomi dengan menggunakan metode PBP, NPV, IRR dan PI menunjukkan hasil yang layak untuk diterima karena memberikan keuntungan kepada pengguna berupa energy saving dan bill saving.

Kata Kunci-Penerangan, Lampu LED, Life Cycle Cost.

\section{PENDAHULUAN}

Permintaan tenaga listrik sektor komersial akan meningkat dengan semakin bertambahnya bangunan komersial seperti hotel, perkantoran dan bangunan mall. Semakin banyaknya gedung perkantoran yang dibangun maka konsumsi listrik juga meningkat. Kebutuhan akan lampu sebagai penerangan juga meningkat. Jumlah perkantoran yang mempunyai pembangkit listrik sendiri itu masih terbatas jumlahnya. Sisanya masih membeli listrik dari PLN melalui gardu-gardu listrik yang ada. Penggunaan listrik di perkantoran memang tidak hanya untuk penerangan saja, seperti untuk penggunaan server, komputer, AC (Air Conditioner), dan lain sebagainya.

Pada penelitian ini penulis mengambil fokus pada sektor penerangannya saja, dan penelitian ini hanya dilakukan di lingkungan gedung Kantor Wilayah (Kanwil) BRI Denpasar. Penggunaan lampu yang banyak tentu bisa menjadi masalah tersendiri. Permasalahan tersebut merupakan permasalahan yang menarik untuk diteliti dan diselesaikan. Karena listrik yang digunakan oleh gedung Kanwil BRI Denpasar merupakan listrik dari PLN, tentu ini akan membantu menemukan cara untuk bisa mendapatkan penerangan yang dibutuhkan dengan biaya pengeluaran seminimal mungkin.

Dengan adanya penelitian ini diharapkan ada hasil yang memberikan penggambaran manakah lampu penerangan yang seharusnya diterapkan di gedung Kanwil BRI Denpasar. Apakah lebih baik menggunakan lampu hemat energi yang lebih kecil dayanya, lebih lama life time-nya, tetapi mahal harga produknya. Atau lebih baik menggunakan lampu biasa yang dayanya besar, life time-nya sebentar, tetapi murah harga produknya.

Penelitian tentang prediksi umur lampu sebelumnya telah dilakukan oleh Jiajie Fan, yaitu membandingkan distribusi life

p-ISSN:1693 - 2951; e-ISSN: 2503-2372

Muhammad Hari Wijaya: Analisis Retrofit Lampu Di ... 
time lumen lampu LED dengan model statistik memperlihatkan adanya kecenderungan kuat cahaya sedikit menurun mencapai penyalaan 10.000 jam. Dengan cara ekstrapolasi, didapatkan bahwa kuat cahaya lampu menurun hingga akan terjadi pada jam 16.000 s.d 20.000 [1].

Hasil pengujian lampu LED sebanyak 59 unit yang dipasarkan di Indonesia menunjukkan bahwa semua sampel yang diuji masih tetap dapat menyala dengan baik walaupun mengalami penurunan kuat cahayanya rata-rata sebesar $16,9 \%$ setelah dinyalakan 6000 jam cahaya awal. Hasil pengujian juga menunjukkan terdapat 57 unit lampu (96,6\%) dari 59 unit lampu masih mampu mengeluarkan kuat cahaya di atas 50\% dari kuat cahaya awal. Atau $89,8 \%$ lampu yang diuji masih mampu menghasilkan kuat cahaya di atas $70 \%$ setelah dinyalakan 6000 jam. Dengan cara ekstrapolasi didapatkan bahwa lampu tersebut mempunyai life time rata-rata sekitar 20.500 jam [2].
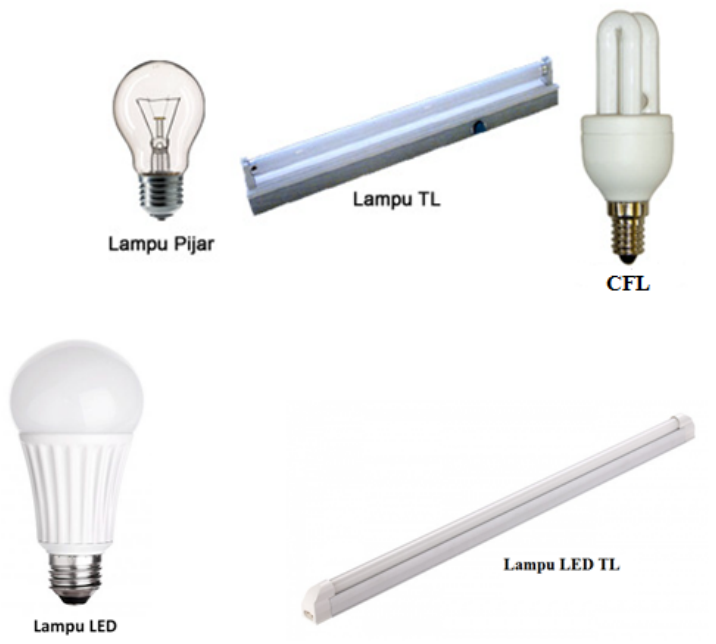

Gambar 1: Jenis-Jenis Lampu

\section{ANALISIS RETROFIT LAMPU DENGAN METODE LIFE CYCLE COST}

\section{A. Life Cycle Cost (LCC)}

Life cycle costs adalah perkiraan total biaya yang dikeluarkan dalam desain, pengembangan, produksi, operasi, pemeliharaan, dukungan, dan disposisi akhir sistem utama untuk mengantisipasi penggunaan rentang umur hidupnya[3].

Life cycle cost suatu barang merupakan jumlah dari semua dana yang dikeluarkan untuk mendukung item dari perusahaan konsepsi dan fabrikasi melalui operasi sampai dengan akhir masa pakainya[4].

Dari sudut pandang manajemen aset, life cycle cost didefinisikan sebagai biaya dari beberapa tahapan, mulai dari desain, pengembangan, manufaktur, operasional dan pembuangan[5].

LCC (biaya siklus hidup) sistem dirumuskan sebagai berikut [6][7] :

$$
\mathrm{LCC}=\mathrm{C}+\mathrm{MPW}+\mathrm{RPW}
$$

Dimana:
LCC = LCC total dalam nilai uang sekarang (Biaya siklus hidup).

C = Capital Cost / Invesment Cost (Biaya Investasi).

MPW = Maintenance / Operating Cost (Biaya Operasi) adalah total biaya pemeliharaan dan operasional selama n tahun atau selama umur proyek.

RPW = Replacement Cost adalah total biaya penggantian yang harus dikeluarkan selama umur proyek.

Faktor diskonto (discount factor) merupakan faktor yang digunakan untuk menilai sekarang akan penerimaanpenerimaan di masa mendatang sehingga dapat dibandingkan dengan pengeluran pada masa sekarang[8]. Sedangkan tingkat diskonto yang digunakan untuk menilai sekarang akan penerimaan-penerimaan tersebut dapat berupa tingkat suku bunga pasar (tingkat suku bunga bank).

Studi kelayakan ekonomi adalah penilaian tentang tidak dapatnya suatu proyek (biasanya merupakan proyek investasi) dilaksanakan dengan berhasil[9]. Untuk menganalisa secara ekonomi kelayakan nilai retrofit lampu ini, akan dianalisa dengan mempergunakan 4 (empat) parameter yaitu : PI (Profitability Index), PBP (Pay Back Period), IRR (Internal Rate of Return) dan NPV (Net Present Value).

\section{Pay Back Period (PBP)}

PBP adalah sebuah parameter yang menghitung seberapa cepat waktu yang diperlukan untuk mengembalikan suatu investasi, sehingga satuan yang dipergunakan adalah tahun, bulan dan hari.

$$
\text { Payback Period }=\frac{\text { Investasi }}{\text { Biaya Operasi }}
$$

Sebagai kriteria penilaiannya adalah apabila nilai PBP-nya lebih panjang dari waktu yang disyaratkan maka proyek ditolak, sedangkan apabila waktunya lebih pendek maka proyek diterima.

\section{Net Present Value (NPV)}

Parameter NPV adalah sebuah parameter dengan mempergunakan suatu tingkat bunga yang relevan untuk menghitung selisih antara nilai sekarang investasi dengan nilai sekarang penerimaan kas bersih dengan memperhitungkan operasional cash flow[10].

$$
N P V=\sum_{t=1}^{n} \frac{B_{t}-C_{t}}{(1+i)^{t}}
$$

Dimana:

$\begin{array}{ll}\mathrm{Bt} & \text { : Keuntungan kotor periode-t } \\ \mathrm{Ct} & \text { : Biaya investasi kotor periode-t } \\ \mathrm{n} & \text { : Umur ekonomi proyek } \\ \mathrm{i} & \text { : Tingkat suku bunga }\end{array}$

Sebagai kriteria penilaian kelayakannya adalah apabila nilai sekarang penerimaan total cash bersihnya lebih besar 
dari total nilai sekarang investasi maka proyek tersebut dinyatakan menguntungkan, sedangkan sebaliknya apabila nilai sekarang penerimaan lebih kecil dari nilai investasi, maka proyek tidak menguntungkan.

\section{E. Internal Rate of Return (IRR)}

Parameter IRR adalah parameter yang dipergunakan untuk mendapatkan tingkat bunga yang menyamakan total nilai sekarang penerimaan arus kas yang diharapkan dengan total nilai sekarang yang diperlukan untuk investasi. Untuk kriteria keputusannya ditentukan oleh nilai IRR yang didapatkan, jika nilai IRR lebih besar dari nilai suku bunga yang umum berlaku maka proyek diterima dan sebaliknya proyek ditolak apabila nilai IRR lebih kecil dari suku bunga yang berlaku[11].

$$
I R R=i+\left\{\frac{N P V}{N P V^{1}-N P V^{2}}\left(i^{1}-i^{2}\right)\right\}
$$

Dimana :

$\mathrm{i} \quad=$ Tingkat suku bunga

$\mathrm{i}^{1} \quad=$ Tingkat suku bunga yang bisa menghasilkan nilai positif NPV

$\mathrm{i}^{2}=$ tingkat suku bunga yang bisa menghasilkan nilai negatif NPV

$\mathrm{NPV}^{1}=$ Nilai positif NPV

$\mathrm{NPV}^{2}=$ Nilai negatif NPV

\section{F. Profitability Index (PI)}

Parameter profitability adalah perbandingan antara nilai sekarang penerimaan arus kas dengan nilai sekarang pengeluaran arus kas. Sebagai kriteria dalam menentukan penerimaaan proyek ditentukan dari nilai PI, proyek dinyatakan diterima apabila nilai PI nya sama atau lebih besar dari 1 , sedangkan sebaliknya proyek ditolak apabila nilainya lebih kecil dari 1.

$$
P I=\frac{P V \text { Penerimaan }}{P V \text { Pengeluaran }}
$$

\section{METODE PENELITIAN}

Pada penelitian ini dilakukan perhitungan penghematan lampu hemat energi menggunakan metode Life Cycle Cost Analysis (LCCA). Lampu yang diteliti adalah TL, CFL, dan lampu LED. Disamping itu juga dilakukan pengecekan kebenaran seberapa persen penghematannya. Adapun komponen suplementer yang digunakan adalah Electricity Consumption (EC), Energi Saving (ES), Bill Saving (BS), Operating Cost (OC), dengan parameter kelayakan ekonomi yang digunakan adalah Pay Back Period (PBP), Net Present Value (NPV), Internal Rate Of Return (IRR), dan Profitability Index (PI).

Muhammad Hari Wijaya: Analisis Retrofit Lampu Di ...
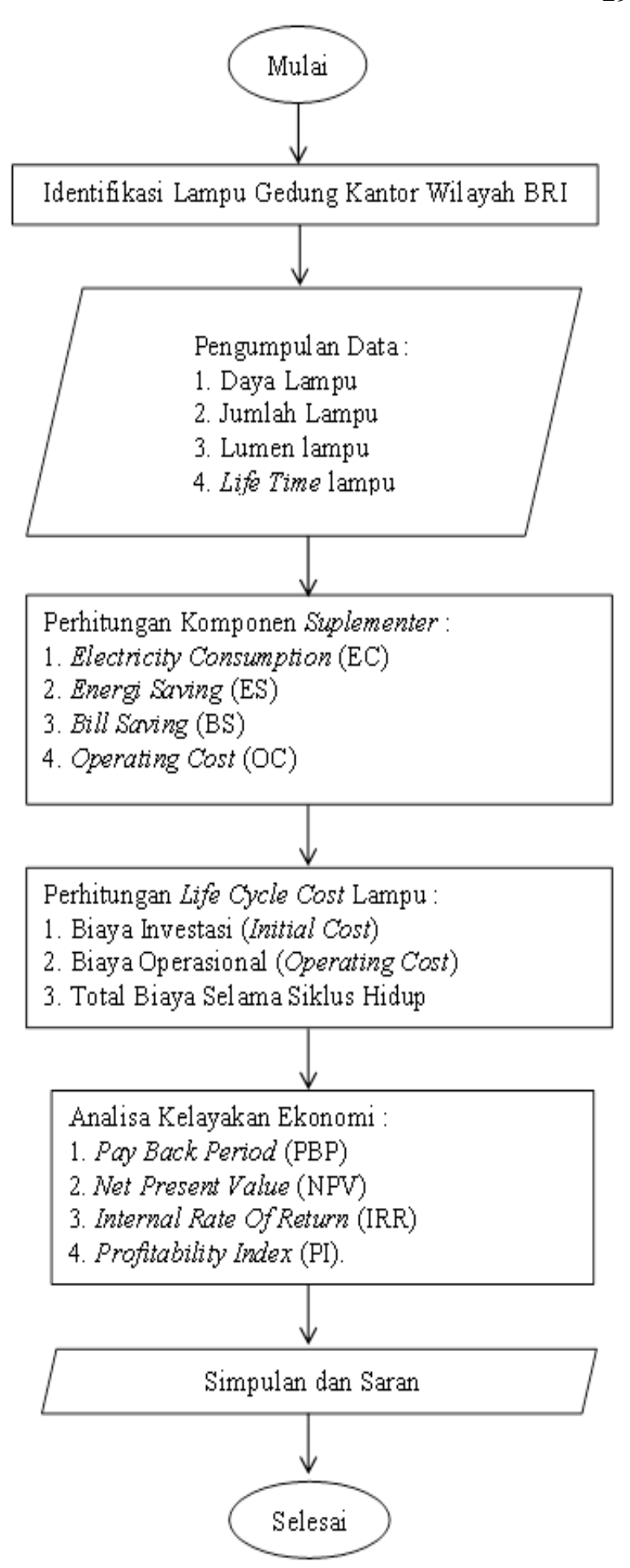

Gambar 1: Diagram Alur Penelitian

\section{HASIL DAN PEMBAHASAN}

\section{A. Rencana Retrofit Lampu}

Kriteria lampu LED Philips yang akan digunakan untuk menggantikan lampu TL dan CFL adalah sebagai berikut :

1. Memiliki nilai lumen tidak kurang dari $2 X$ nilai lumen lampu yang digantikan.

2. Tersedia dipasar Indonesia. 
TABEL I

RENCANA RETROFIT LAMPU KANWIL BRI DENPASAR

\begin{tabular}{|c|c|c|c|c|c|c|c|}
\hline \multirow{2}{*}{ No. } & \multicolumn{3}{|c|}{ Lampu Existing } & \multicolumn{3}{c|}{ Lampu Pengganti } & \multirow{2}{*}{$\begin{array}{c}\text { Perbandingan } \\
\text { Lumen }\end{array}$} \\
\cline { 2 - 8 } & Tipe Lampu & Daya (Watt) & Lumen & Tipe Lampu & Daya (Watt) & Lumen & \\
\hline 1 & TL & 18 & 1050 & LED Tube & 8 & 800 & 1.31 \\
\hline 2 & TL & 36 & 2500 & LED Tube & 16 & 1600 & 1.56 \\
\hline 3 & CFL Essential & 18 & 1100 & LED Bulb & 10,5 & 1055 & 1.04 \\
\hline 4 & CFL Essential & 23 & 1420 & LED Bulb & 10,5 & 1055 & 1.35 \\
\hline 5 & CFL Essential & 50 & 3100 & LED Bulb & 27 & 3000 & 1.03 \\
\hline
\end{tabular}

Berikut spesifikasi dan harga lampu LED Philips yang akan digunakan dalam retrofit lampu :

TABEL II

SPESIFIKASI DAN HARGA LAMPU LED PHILIPS

\begin{tabular}{|c|c|c|c|c|c|}
\hline No. & Tipe Lampu & Daya (Watt) & Lumen & Life Time (Jam) & Harga (Rp) \\
\hline 1 & LED Tube & 8 & 800 & 15000 & $54.000,00$ \\
\hline 2 & LED Tube & 16 & 1600 & 15000 & $66.000,00$ \\
\hline 3 & LED Bulb & 10,5 & 1055 & 25000 & $55.000,00$ \\
\hline 4 & LED Bulb & 27 & 3000 & 25000 & $134.000,00$ \\
\hline
\end{tabular}

\section{B. Perhitungan Initial Cost Dan Annual Cost Lampu}

Berikut adalah perhitungan Initial Cost dan Annual Cost dari penggunaan lampu existing dan lampu retrofitting.

TABEL III

INITIAL COST PENGGUNAAN LAMPU EXISTING

\begin{tabular}{|c|c|c|c|c|}
\hline No. & Pembelian Lampu & Jumlah Lampu & $\begin{array}{l}\text { Harga Satuan } \\
(\mathrm{Rp})\end{array}$ & $\begin{array}{c}\text { Total Biaya/Unit } \\
(\mathrm{Rp})\end{array}$ \\
\hline 1 & TL 18 Watt & 1491 & Rp $19.000,00$ & $\operatorname{Rp} 28.329 .000,00$ \\
\hline 2 & TL 36 Watt & 157 & Rp $24.000,00$ & Rp $3.768 .000,00$ \\
\hline 3 & CFL Essential 18 Watt & 309 & Rp $45.000,00$ & Rp 13.905.000,00 \\
\hline 4 & CFL Essential 23 Watt & 24 & Rp $54.000,00$ & $\begin{array}{ll}\text { Rp } & 1.296 .000,00 \\
\end{array}$ \\
\hline 5 & CFL Essential 50 Watt & 12 & Rp129.000,00 & $\begin{array}{ll}\text { Rp } & 1.548 .000,00 \\
\end{array}$ \\
\hline \multicolumn{4}{|c|}{ Total Biaya (Rp) } & Rp 48.846.000,00 \\
\hline
\end{tabular}

TABEL IV

ANNUAL COST PENGGUNAAN LAMPU EXISTING

\begin{tabular}{|c|c|c|c|c|c|c|}
\hline No. & Pembelian Lampu & $\begin{array}{l}\text { Jumlah } \\
\text { Lampu }\end{array}$ & $\begin{array}{c}\text { Pemakaian } \\
\text { (jam/hari) }\end{array}$ & $\begin{array}{c}\text { Daya } \\
\text { (KWatt) }\end{array}$ & Biaya/KWh & $\begin{array}{c}\text { Total } \\
\text { Biaya/Unit/KWh }\end{array}$ \\
\hline 1 & TL 18 Watt & 1491 & 18 & 0,018 & Rp1.117,00 & $\mathrm{Rp} \quad 539.605$ \\
\hline 2 & TL 36 Watt & 157 & 18 & 0,036 & Rp1.117,00 & 113.639 \\
\hline 3 & CFL Essential 18 Watt & 309 & 18 & 0,018 & Rp1.117,00 & 111.830 \\
\hline 4 & CFL Essential 23 Watt & 24 & 18 & 0,023 & Rp1.117,00 & 11.099 \\
\hline 5 & CFL Essential 50 Watt & 12 & 18 & 0,05 & Rp1.117,00 & 12.064 \\
\hline \multicolumn{6}{|c|}{ Total Biaya/hari (Rp) } & 788.236 \\
\hline \multicolumn{6}{|c|}{ Total Biaya/bulan (Rp) } & Rp 23.647.069 \\
\hline & \multicolumn{5}{|c|}{ Total Biaya/tahun (Rp) } & $\operatorname{Rp} 283.764 .825$ \\
\hline
\end{tabular}

\section{Perhitungan Lampu Rencana Retrofitting}

Berikut adalah perhitungan Initial Cost dan Annual Cost apabila di retrofitting dengan lampu LED.

TABEL V

INITIAL COST PENGGUNAAN LAMPU LED

\begin{tabular}{|c|c|c|c|c|}
\hline No. & Pembelian Lampu & Jumlah Lampu & $\begin{array}{c}\text { Harga Satuan } \\
(\mathrm{Rp})\end{array}$ & Total Biaya/Unit (Rp) \\
\hline 1 & LED Tube 8 Watt bundled fitting & 1491 & $\mathrm{Rp} \mathrm{75.000,00}$ & $\mathrm{Rp} \mathrm{111.825.000,00}$ \\
\hline 2 & LED Tube 16 Watt bundled fitting & 157 & $\mathrm{Rp} 85.000,00$ & $\mathrm{Rp} 13.345 .000,00$ \\
\hline 3 & LED Bulb 10,5 Watt & 333 & $\mathrm{Rp} \mathrm{55.000,00}$ & $\mathrm{Rp} 18.315 .000,00$ \\
\hline 4 & LED Bulb 27 Watt & 12 & $\mathrm{Rp} 134.000,00$ & $\mathrm{Rp} 1.608 .000,00$ \\
\hline \multicolumn{6}{|c|}{ Total Biaya (Rp) } & $\operatorname{Rp~145.093.000,00~}$ \\
\hline
\end{tabular}

TABEL VI

ANNUAL COST PENGGUNAAN LAMPU LED

\begin{tabular}{|c|c|c|c|c|c|c|}
\hline No. & Pembelian Lampu & $\begin{array}{l}\text { Jumlah } \\
\text { Lampu } \\
\end{array}$ & \begin{tabular}{|c|}
$\begin{array}{c}\text { Pemakaian } \\
\text { (jam/hari) }\end{array}$ \\
\end{tabular} & \begin{tabular}{|c|} 
Daya \\
(KWatt)
\end{tabular} & Biaya/KWh & $\begin{array}{c}\text { Total } \\
\text { Biaya/Unit/KWh }\end{array}$ \\
\hline 1 & LED Tube 8 Watt & 1491 & 18 & 0,008 & Rp1.117,00 & Rp $\quad 239.824$ \\
\hline 2 & LED Tube $16 \mathrm{Watt}$ & 157 & 18 & 0,016 & Rp1.117,00 & 50.506 \\
\hline 3 & LED Bulb 10,5 Watt & 333 & 18 & 0,0105 & Rp1.117,00 & 70.301 \\
\hline 4 & LED Bulb 27 Watt & 12 & 18 & 0,027 & Rp1.117,00 & 6.514 \\
\hline \multicolumn{6}{|c|}{ Total Biaya/hari (Rp) } & $\mathrm{Rp} \quad 367.146$ \\
\hline \multicolumn{6}{|c|}{ Total Biaya/bulan (Rp) } & $\begin{array}{ll}\mathrm{Rp} & 11.014 .368 \\
\end{array}$ \\
\hline \multicolumn{6}{|c|}{ Total Biaya/tahun (Rp) } & Rp132.172.421 \\
\hline
\end{tabular}

\section{Perhitungan Electricity Consumption (EC)}

Total Energy Consumption dihitung untuk mengetahui seberapa besar perbedaan energi yang dibutuhkan jika dilakukan penggantian lampu di gedung Kantor Wilayah BRI Denpasar. Dengan cara dilakukan penghitungan penggunaan energi dari masing-masing kebutuhan energi antara lampu existing dengan lampu LED dengan lama pemakaian per hari $(\mathrm{OH})$ adalah 18 jam.

TABEL VII

EC LAMPU EXISTING

\begin{tabular}{|c|c|c|c|c|c|}
\hline No. & Jenis Lampu & Jumlah Lampu & $\begin{array}{c}\text { Daya } \\
\text { (KWatt) }\end{array}$ & $\begin{array}{c}\text { Pemakaian } \\
\text { (jam/hari) }\end{array}$ & EC /Bulan (KWh) \\
\hline 1 & TL 18 Watt & 1491 & 0,018 & 18 & 14492,52 \\
\hline 2 & TL 36 Watt & 157 & 0,036 & 18 & 3052,08 \\
\hline 3 & CFL Essential 18 Watt & 309 & 0,018 & 18 & 3003,48 \\
\hline 4 & CFL Essential 23 Watt & 24 & 0,023 & 18 & 298,08 \\
\hline 5 & CFL Essential 50 Watt & 12 & 0,05 & 18 & 324 \\
\hline \multicolumn{6}{|c|}{ Total EC Existing } \\
\hline
\end{tabular}

TABEL VIII

EC LAMPU LED

\begin{tabular}{|c|c|c|c|c|c|}
\hline No. & Jenis Lampu & Jumlah Lampu & $\begin{array}{c}\text { Daya } \\
\text { (KWatt) }\end{array}$ & $\begin{array}{c}\text { Pemakaian } \\
\text { (jam/hari) }\end{array}$ & EC /Bulan (KWh) \\
\hline 1 & LED Tube 8 Watt & 1491 & 0,008 & 18 & 6441,12 \\
\hline 2 & LED Tube 16 Watt & 157 & 0,016 & 18 & 1356,48 \\
\hline 3 & LED Bulb 10,5 Watt & 333 & 0,0105 & 18 & 1888,11 \\
\hline 4 & LED Bulb 27 Watt & 12 & 0,027 & 18 & 174,96 \\
\hline \multicolumn{7}{|c|}{ Total EC LED } \\
\hline
\end{tabular}

E. Perhitungan Energy Saving (ES)

Energy saving atau penghematan energi per bulan didapatkan dari mengurangkan total konsumsi energi lampu existing dengan total konsumsi energi lampu retrofitting yaitu lampu LED, dengan hasil sebagai berikut :

$$
\mathrm{ES}=\mathrm{EC} \text { existing }-\mathrm{EC} \text { retrofitting }
$$

Maka ES = 21.170,16 - 9.860,67 = 11.309,49 kWh

\section{F. Perhitungan Bill Saving (BS)}

Bill saving atau penghematan biaya per bulan akan didapatkan dengan cara mengalikan jumlah penghematan energi yang diperoleh dari penggunaan lampu LED dengan harga tarif listrik per $\mathrm{kWh}$ (ET) yang dibebankan dari pemerintah kepada Bank BRI Denpasar yaitu sebesar Rp.1.117,00 dengan hasil perhitungan sebagai berikut :

$$
\mathrm{BS}=\mathrm{ES} \mathrm{X} \mathrm{ET}
$$

Maka BS $=11.309,49$ X 1.117,00 = 12.632.700,3

G. Perhitungan Operating Cost (OC) 
Operating Cost atau biaya operasi hanya untuk melihat total biaya per hari yang akan dikeluarkan jika melakukan penggantian lampu existing dengan lampu LED, dengan cara mengalikan jumlah lampu, jam pemakaian per hari, daya lampu, dan tarif listrik (ET). Adapun perhitungannya sebagai berikut :

TABEL IX

OC LAMPU LED

\begin{tabular}{|c|c|c|c|c|c|cr|}
\hline No. & Pembelian Lampu & $\begin{array}{c}\text { Jumlah } \\
\text { Lampu }\end{array}$ & $\begin{array}{c}\text { Pemakaian } \\
\text { (jam/hari) }\end{array}$ & $\begin{array}{c}\text { Daya } \\
\text { (KWatt) }\end{array}$ & Biaya/KWh & $\begin{array}{c}\text { Total } \\
\text { Biaya/Unit/KWh }\end{array}$ \\
\hline 1 & LED Tube 8 Watt & 1491 & 18 & 0,008 & $\mathrm{Rp} 1.117,00$ & $\mathrm{Rp}$ & 239.824 \\
\hline 2 & LED Tube 16 Watt & 157 & 18 & 0,016 & $\mathrm{Rp} 1.117,00$ & $\mathrm{Rp}$ & 50.506 \\
\hline 3 & LED Bulb 10,5 Watt & 333 & 18 & 0,0105 & $\mathrm{Rp} 1.117,00$ & $\mathrm{Rp}$ & 70.301 \\
\hline 4 & LED Bulb 27 Watt & 12 & 18 & 0,027 & $\mathrm{Rp} 1.117,00$ & $\mathrm{Rp}$ & 6.514 \\
\hline \multicolumn{6}{|c|}{ Total Biaya/hari (Rp) } & $\mathrm{Rp}$ & 367.146 \\
\hline
\end{tabular}

\section{H. Total Operational Cost (OC) Lampu Existing}

Berikut adalah total operational cost lampu existing Kanwil BRI Denpasar yang memiliki life time 13.000 jam atau sekitar 2 tahun yang akan mengalami gradasi sebesar rata-rata angka inflasi yang terjadi yaitu sebesar 4,2\% (Januari 2015 - Januari 2019, sumber : bi.go.id).

TABEL $X$

TOTAL BIAYA OC LAMPU EXISTING

\begin{tabular}{|c|c|c|}
\hline Tahun Ke & Tahun & $\begin{array}{c}\text { Biaya Operasional } \\
(\text { OC) dengan gradasi } \\
4,2 \% / \text { tahun }\end{array}$ \\
\hline 0 & 2019 & 0 \\
\hline 1 & 2020 & $\operatorname{Rp~283.764.824,64~}$ \\
\hline 2 & 2021 & $\operatorname{Rp~295.682.947,27~}$ \\
\hline \multicolumn{2}{|c|}{ Jumlah } & Rp 579.447.771,91 \\
\hline
\end{tabular}

\section{Total Operational Cost (OC) Lampu LED}

Tabel XI menyajikan perhitungan present value dari biaya operasional lampu LED dengan mempergunakan tingkat suku bunga sebesar $9,95 \%$.(sesuai dengan rata-rata bunga pinjaman yang berlaku dibeberapa bank yang ada di Indonesia). Present value dihitung dengan persamaan : $\mathrm{P}=\mathrm{F} /(1+\mathrm{i})^{\mathrm{n}}$ sehingga total present value dari biaya operasional (OC) LED adalah sebesar Rp. 444.423.626,13.

TABEL XI

TOTAL BIAYA OC LED

\begin{tabular}{|c|c|c|c|c|cc|}
\hline No. & Tahun & $\begin{array}{c}\text { Biaya Operasional } \\
(\mathrm{OC}) \text { dengan gradasi } \\
4,2 \% / \text { tahun }\end{array}$ & $\begin{array}{c}\text { 1/DF pada tingkat } \\
\text { suku bunga } 9,95 \%\end{array}$ & Present Value OC \\
\hline 0 & 2019 & 0 & 1 & & 0 \\
\hline 1 & 2020 & $\mathrm{Rp}$ & $132.172 .421,00$ & 0,910 & $\mathrm{Rp}$ & $120.211 .387,90$ \\
\hline 2 & 2021 & $\mathrm{Rp}$ & $137.723 .662,68$ & 0,827 & $\mathrm{Rp}$ & $113.924 .753,25$ \\
\hline 3 & 2022 & $\mathrm{Rp}$ & $143.508 .056,51$ & 0,752 & $\mathrm{Rp}$ & $107.966 .887,57$ \\
\hline 4 & 2023 & $\mathrm{Rp}$ & $149.535 .394,89$ & 0,684 & $\mathrm{Rp}$ & $102.320 .597,41$ \\
\hline \multicolumn{2}{|c|}{ Jumlah } & $\mathrm{Rp}$ & $562.939 .535,08$ & & $\mathrm{Rp}$ & $444.423 .626,13$ \\
\hline
\end{tabular}

\section{J. Total LCC}

Dengan menjumlahkan komponen Initial Cost dan Operational Cost maka didapatkan total nilai LCC lampu. Total LCC lampu LED yaitu Rp. 708.032.535,08 dengan jangka waktu 4 (empat) tahun, sedangkan total LCC lampu existing yaitu Rp. Rp 628.293.771,91 dengan jangka waktu 2 (dua) tahun.

Muhammad Hari Wijaya: Analisis Retrofit Lampu Di ...

K. Perhitungan Pay Back Period (PBP)

$$
\text { Pay Back Period }=\frac{\text { Investasi Aswal }}{\text { Bin Saving }}
$$

$$
\text { Maka PBP }=\frac{\operatorname{Rp} 145,093,000}{\operatorname{Rp} 12,632,700,3}=11,48
$$

Kanwil BRI Denpasar akan mengalami pay back period pada bulan ke 11, itu berarti lampu LED layak untuk dijadikan lampu pengganti existing mengingat umur lampu LED yang dapat mencapai 25.000 jam atau 3,8 tahun (44 bulan) dengan penggunaan $18 \mathrm{jam} / \mathrm{hari}$ ).

\section{Perhitungan Net Present Value (NPV)}

Berikut ini adalah perhitungan Net Present Value (NPV) dari lampu LED dengan memperhitungkan Present Value (PV) biaya investasi awal dan PV biaya operasional lampu LED selama 4 (empat) tahun dibandingkan dengan bill saving :

TABEL XII PERHITUNGAN NPV LAMPU LED

\begin{tabular}{|c|c|cc|c|cr|}
\hline \multirow{2}{*}{ No. } & Tahun & $\begin{array}{c}\text { Arus Kas dengan gradasi } \\
4,2 \% / \text { tahun }\end{array}$ & $\begin{array}{c}\text { 1/DF pada tingkat } \\
\text { suku bunga } 9,95 \%\end{array}$ & \multicolumn{2}{|c|}{ Present Value } \\
\hline 0 & 2019 & $\operatorname{Rp}$ & $(589.516 .626,13)$ & 1 & $\operatorname{Rp}$ & $(589.516 .626,13)$ \\
\hline 1 & 2020 & $\mathrm{Rp}$ & $151.592 .400,00$ & 0,910 & $\mathrm{Rp}$ & $137.873 .942,70$ \\
\hline 2 & 2021 & $\mathrm{Rp}$ & $157.959 .280,80$ & 0,827 & $\mathrm{Rp}$ & $130.663 .618,28$ \\
\hline 3 & 2022 & $\mathrm{Rp}$ & $164.593 .570,59$ & 0,752 & $\mathrm{Rp}$ & $123.830 .368,57$ \\
\hline 4 & 2023 & $\mathrm{Rp}$ & $171.506 .500,56$ & 0,684 & $\mathrm{Rp}$ & $117.354 .473,90$ \\
\hline
\end{tabular}

NPV menunjukkan nilai positif yang berarti layak dan bisa diterima.

\section{Perhitungan Internal Rate of Return (IRR)}

Hasil perhitungan metode internal rate of return (IRR) yang ditunjukkan dalam tabel XIII, menunjukkan angka $16,42 \%$, angka ini lebih besar dari 9,95\% (tingkat suku bunga yang dipergunakan dalam perhitungan) sehingga layak dan bisa diterima.

TABEL XIII

\begin{tabular}{|c|c|c|c|c|c|c|}
\hline Tahun & Tahun & $\begin{array}{c}\text { Arus Kas dengan gradasi } \\
4,2 \% \text { / tahun }\end{array}$ & \begin{tabular}{|c|}
$1 / \mathrm{DF}$ \\
$1 \%$ \\
\end{tabular} & PV (1\%) & $\begin{array}{l}1 / \mathrm{DF} \\
17 \%\end{array}$ & PV $(17 \%)$ \\
\hline 0 & 2019 & $\begin{array}{ll}\mathrm{Rp} & (444.423 .626,13) \\
\end{array}$ & 1 & $\mathrm{Rp}(444.423 .626,13)$ & 1 & $\operatorname{Rp}(444.423 .626,13)$ \\
\hline 1 & 2020 & $151.592 .400,00$ & 0,990 & $\begin{array}{|ll|}\operatorname{Rp} & 150.091 .485,15 \\
\end{array}$ & 0,855 & Rp $129.566 .153,85$ \\
\hline 2 & 2021 & $157.959 .280,80$ & 0,980 & Rp $154.846 .858,94$ & 0,731 & Rp 115.391.395,13 \\
\hline 3 & 2022 & $164.593 .570,59$ & 0,971 & \begin{tabular}{|l|l|}
$\operatorname{Rp}$ & $159.752 .898,03$ \\
\end{tabular} & 0,624 & $\begin{array}{l}\text { Rp 102.767.379,26 } \\
\end{array}$ \\
\hline 4 & 2023 & $\begin{array}{|ll|}\mathrm{Rp} & 171.506 .500,56 \\
\end{array}$ & 0,961 & $\begin{array}{ll}\mathrm{Rp} & 164.814 .375,99 \\
\end{array}$ & 0,534 & Rp $\quad 91.524 .452,30$ \\
\hline \multicolumn{4}{|c|}{ PV Total Investasi } & Rp $(444.423 .626,13)$ & & $\mathrm{Rp}(444.423 .626,13)$ \\
\hline \multicolumn{4}{|c|}{ PV Total Penghematan } & $\begin{array}{ll}\mathrm{Rp} & 629.505 .618,10 \\
\end{array}$ & & Rp 439.249.380,53 \\
\hline \multicolumn{4}{|c|}{ NPV } & $\begin{array}{ll}\text { Rp } & 185.081 .991,97 \\
\end{array}$ & & $\operatorname{Rp} \quad(5.174 .245,60)$ \\
\hline \multicolumn{6}{|c|}{ IRR } & $16,42 \%$ \\
\hline
\end{tabular}

PERHITUNGAN IRR LAMPU LED

\section{N. Perhitungan Profitability Index (PI)}

Profitability Index atau benefit cost ratio adalah rasio antara present value (PV) penerimaan arus kas dengan present value pengeluaran arus kas. Sesuai dengan hasil perhitungan dimana :

PV Pendapatan = Rp. 645.651.751,95

PV Pengeluaran $=$ Rp. 589.516.626,13

p-ISSN:1693 - 2951; e-ISSN: 2503-2372 


$$
\mathrm{PI}=\frac{\text { PV Pendapatan }}{\text { pV Pengeluaran }}
$$

Sehingga PI adalah sebesar 1,095 (diatas satu) menunjukkan layak diterima dan memberikan keuntungan.

\section{KESIMPULAN}

Dengan penggantian lampu existing menjadi lampu LED maka akan diperoleh energy saving sebesar 11.309,49 kWh setiap bulannya, sehingga akan diperoleh bill saving sebesar Rp. 12.632.700,00 setiap bulannya. LCC lampu LED yaitu sebesar Rp. 708.032.535,08 dengan jangka waktu 4 (empat) tahun lebih panjang dan lebih efisien apabila dibandingkan dengan LCC lampu existing. Berdasarkan perhitungan kelayakan ekonomi dengan menggunakan metode pay back period (PBP), net present value (NPV), internal rate of return (IRR) dan profitability index (PI) maka retrofit lampu Kantor Wilayah BRI Denpasar sangat direkomendasi untuk dilakukan.

\section{REFERENSI}

[1] Xi Yang, Bo Sun, Zili Wang, Cheng Qian, Yi Ren, Dezhen Yang, and Qiang Feng, "An Alternative Lifetime Model for White Light Emitting Diodes under Thermal-Electrical", Materials, Vol. 11, Issue 5, May 2018.
[2] Sudirman Palaloi, "Pengujian Dan Analisis Umur Pakai Lampu Light Emitting Diode (LED) Swabalast Untuk Pencahayaan Umum", 2015.

[3] DOE, Technical Support Document : "Energy Efficiency Standards For Consumer Product And Commercial And Industrial Equipment", U.S Department of Energy, May 2013.

[4] White GE \& Ostwald PF, "Life Cycle Costing", Mgmt Accounting, January, p. 39, 1976.

[5] E.L. Maout, and H. Kato, "Life Cycle Cost-Estimation Model for Building, Operating, and Maintaining High-Speed Rail Systems", Asian Transport Studies, Vol. 4, pp. 245-260, Issue 1, 2016.

[6] Chowdhury Akram Hossain, Nusrat Chowdhury, Michela Longo, and Wahiba Yaïci, "'System and Cost Analysis of Stand-Alone Solar Home System Applied to a Developing Country", MDPI, Vol. 11(5), pp. 1-13, March 2019.

[7] Foster, R. Ghassemi M, Cota, A, "Solar Energy Renewable Energy and The Environment", Boca Raton FL, CRC Press, 2010.

[8] Halim, A., "Analisis Kelayakan Investasi”, Graha Ilmu, Yogyakarta, 2009.

[9] Suad Husnan, Suwarsono Muhammad, "Studi Kelayakan Proyek", UPP AMP YKPN, Yogyakarta, 2000.

[10] Sugirianta, Ida Bagus Ketut, Giriantari, IAD, and Kumara, I Nyoman. "Analisa Keekonomian Tarif Penjualan Listrik Pembangkit Listrik Tenaga Surya 1 MWp Bangli Dengan Metode Life Cycle Cost" Majalah Ilmiah Teknologi Elektro [Online], Vol. 15 Number 2 (4 December 2016).

[11] Kadariah, "Pengantar Evaluasi Proyek", Lembaga Penerbit FE UI, Jakarta, 1999. 